\title{
Interferon $\gamma$ and Interleukin 4 Stimulate Prolonged Expression of Inducible Nitric Oxide Synthase in Human Airway Epithelium through Synthesis of Soluble Mediators
}

\author{
Fuhua H. Guo, ${ }^{\star \ddagger}$ Kohsaku Uetani, ${ }^{\star \ddagger}$ S. Jaharul Haque, ${ }^{\ddagger}$ Bryan R.G. Williams, ${ }^{\ddagger}$ Raed A. Dweik, ${ }^{\star}$ Frederik B.J.M. Thunnissen, ${ }^{\S}$ \\ William Calhoun, and Serpil C. Erzurum ${ }^{\star \ddagger}$ \\ $*$ Department of Pulmonary and Critical Care Medicine and ${ }^{\ddagger}$ Department of Cancer Biology, Cleveland Clinic Foundation, Cleveland,

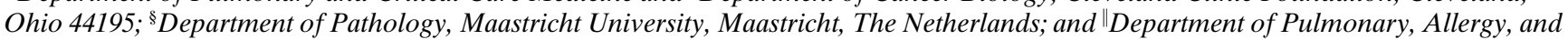 \\ Critical Care Medicine, University of Pittsburgh, Pittsburgh, Pennsylvania 15213
}

\begin{abstract}
Human respiratory epithelium expresses inducible nitric oxide synthase (iNOS) continuously in vivo, however mechanisms responsible for maintenance of expression are not known. We show that IFN $\gamma$ is sufficient for induction of iNOS in primary human airway epithelial cells (HAEC) in vitro, and IL-4 potentiates IFN $\gamma$-induced iNOS expression in HAEC through stabilization of iNOS mRNA. IFN $\gamma / \mathrm{IL}-4$ induced iNOS expression in HAEC was delayed in onset and prolonged with expression up to $1 \mathrm{wk}$. Removal of overlying culture media resulted in loss of expression, while transfer of conditioned media induced iNOS mRNA in other HAEC. IFN $\gamma$ and IL-4 stimulation activated STAT1 and STAT6 in HAEC, but conditioned media transfer to HAEC produced even higher levels of STAT1 activation than achieved by direct addition of cytokines. Although cytokine induction of iNOS was dependent on new protein synthesis, conditioned media induction of iNOS in HAEC was not. Further, removal of overlying culture media from cells at different times after cytokine stimulation demonstrated that mediator synthesis and/or secretion important for induction and maintenance of iNOS occurs early after cytokine stimulation. In conclusion, a combination of IFN $\gamma$ / IL-4, which occurs naturally in the lung epithelial lining fluid, leads to maintenance of iNOS expression in human airway epithelium through production of soluble mediators and stabilization of mRNA. (J. Clin. Invest. 1997. 100:829838.) Key words: signal transduction - messenger RNA • gene expression regulation $\bullet$ nitric oxide $\bullet$ cycloheximide
\end{abstract}

\section{Introduction}

Nitric oxide (NO) $)^{1}$ produced in the lungs is an important regulator of airway events, including modifying airway tone, regulating pulmonary vascular tone, stimulating mucin secretion, modulating mucociliary clearance through effects on ciliary

Address correspondence to Serpil C. Erzurum, M.D., Cleveland Clinic Foundation, 9500 Euclid Avenue/A90, Cleveland, OH 44195. Phone: 216-445-6624; FAX: 216-445-6269; E-mail: erzurus@cesmtp. ccf.org

Received for publication 6 July 1994 and accepted in revised form 13 May 1997.

J. Clin. Invest.

(C) The American Society for Clinical Investigation, Inc. 0021-9738/97/08/0829/10 \$2.00

Volume 100, Number 4, August 1997, 829-838

http://www.jci.org beat frequency, and immune surveillance including tumoricidal and bactericidal effects (1). Three types of nitric oxide synthases (NOS: EC 1.14.13.39), the enzymes responsible for endogenous NO production, have been described in human cells: inducible NOS (iNOS) which produces high levels of NO, and two constitutive NOS which produce low levels of NO $(2,3)$. We have shown previously that normal human airway epithelial cells in vivo produce NO through the continuous expression of iNOS (4). Expression of the iNOS mRNA and protein is detected in epithelial cells in the normal, noninflamed upper and lower airway by a variety of techniques including Northern and in situ hybridization, and Western and immunohistochemistry (4-6). The continuous iNOS expression in human airway epithelial cells is in contrast to other cell types that do not express iNOS unless induced by cytokines, such as IFN $\gamma$, IL- $1 \beta$, and/or $\operatorname{TNF} \alpha(3,7)$. Interestingly, although human airway epithelium expresses abundant levels of iNOS in vivo, culture of the human airway cells ex vivo leads to loss of iNOS gene expression (4). These findings suggest that the control of iNOS expression in human airway epithelium is dependent upon a combination of in vivo factor(s) or exposures to which airway epithelial cells are uniquely responsive.

As yet, the mechanisms that regulate iNOS expression have only been partially characterized in a small number of human cell types, such as hepatocytes $(7,8)$. The mechanisms regulating iNOS gene expression in human airway epithelial cells are unknown. Surprisingly, although similar cytokines induce iNOS in murine and human cells, transcriptional control of murine iNOS gene expression appears to be markedly different from the mode of regulation of the human iNOS gene (7-9). Further adding to the complexity of understanding the mechanisms regulating iNOS gene expression, regulation of iNOS varies greatly dependent upon the cell type being studied and/or the stimuli used to induce expression $(8,10,11)$. Here, we describe the mediators responsible for induction and maintenance of iNOS expression in human airway epithelial cells and investigate the mechanisms regulating expression. We show that a combination of IFN $\gamma$ and IL-4 is important for

1. Abbreviations used in this paper: A549, lung adenocarcinoma epithelial cell line; BAL, bronchoalveolar lavage; BEAS2B, transformed human bronchial epithelial cell line; $\mathrm{CD}$, cluster of differentiation; CD23, low affinity IgE receptor; EMSA, electrophoretic mobility shift assay; GAS, IFN $\gamma$ activation site; HAEC, primary human airway epithelial cells; iNOS, inducible nitric oxide synthase; IRF-1, IFN regulatory factor-1; LHC8, Lechner and LaVeck media; L-NMMA, $N^{\mathrm{G}}$-monomethyl-L-arginine; NO, nitric oxide; NOS, nitric oxide synthase; STAT, signal transducers and activators of transcription; THP1, monocytic leukemia cell line; WCE, whole cell extract. 
maintaining the continuous expression of iNOS in human airway epithelial cells through the production of protein synthesis-dependent soluble mediators and stabilization of iNOS mRNA.

\section{Methods}

Sampling of human airway epithelial cells (HAEC) and bronchoalveolar lavage $(B A L)$. HAEC were obtained through bronchoscopy with a flexible fiberoptic bronchoscope (Olympus BS-IT10; Olympus Optical Co., Tokyo, Japan) from normal nonsmoking volunteers ( $n=$ 44,28 male, 16 female, age $30 \pm 8 \mathrm{yr}$, range $18-54 \mathrm{yr}$ ) with no history of lung disease and on no medications. Informed consent was obtained under a protocol approved by the Institutional Review Board at the Cleveland Clinic Foundation. For some experiments, airway epithelial cells were isolated from postmortem tracheas and main bronchi as previously described (12). Bronchoscopic brush samplings of airway epithelial cells were taken from second and third order bronchi as previously described (4). An aliquot of the cells was taken for cell counting and characterization, with the remaining cells used for cell culture, whole cell extraction for electrophoretic mobility shift assay (EMSA), or RNA isolation.

BAL was performed as previously described (13). Briefly, two 60$\mathrm{ml}$ aliquots of warm $\left(37^{\circ} \mathrm{C}\right)$ sterile normal saline solution were infused into a segmental or subsegmental bronchus and then aspirated back. After the cells were removed, the BAL was analyzed for IFN $\gamma$, IL-4, and protein levels.

Cell culture and treatment. HAEC obtained by bronchial brushing were cultured in serum-free Lechner and LaVeck media (LHC8, which includes hydrocortisone $0.72 \mu \mathrm{g} /$ liter, phenol red $1.24 \mu \mathrm{g} / \mathrm{liter}$; Biofluids, Inc., Rockville, MD) on plates precoated with coating media containing $29 \mu \mathrm{g} / \mathrm{ml}$ collagen (vitrogen; Collagen Corp., Palo Alto, CA), $10 \mu \mathrm{g} / \mathrm{ml}$ BSA (Biofluids, Inc.), and $10 \mu \mathrm{g} / \mathrm{ml}$ fibronectin (Calbiochem, La Jolla, CA) for 5 min (4). The cells were passaged at 60 $80 \%$ confluence by dissociation from plates with $0.02 \%$ trypsin (E-PET; Biofluids, Inc.) which was neutralized with soybean trypsin inhibitor (SBTI; Biofluids, Inc.). Primary HAEC cultures of passages 0-2 were used in experiments. BEAS2B, a human bronchial epithelial cell line transformed by Ad12-SV40 virus (a gift from C. Harris, National Cancer Institute [14]), was cultured in serum-free LHC8 with additives $0.33 \mathrm{nM}$ retinoic acid and $2.75 \mu \mathrm{M}$ epinephrine, on precoated plates similar to HAEC.

A549 cells, epithelial cell line derived from lung adenocarcinoma (American Type Culture Collection, Rockville, MD), were cultured in MEM (Gibco Laboratories, Grand Island, NY) with $10 \%$ heatinactivated FBS. Human THP1 monocytic leukemia cells (American Type Culture Collection) were cultured in RPMI 1640 media (Gibco Laboratories) with $50 \mathrm{nM}$ 2-mercaptoethanol, 10\% FBS, $2 \mathrm{mM}$ L-glutamine, $50 \mathrm{U} / \mathrm{ml}$ penicillin, and $50 \mu \mathrm{g} / \mathrm{ml}$ streptomycin.

Human IFN $\gamma$ was a gift from Genentech Inc. (South San Francisco, CA) or from R \& D Systems, Inc. (Minneapolis, MN); recombinant human IL-4 was a gift from Dr. D. Mytych (Schering-Plough Research Institute, Kenilworth, NJ) or from Genzyme Corp. (Cambridge, MA); and recombinant human IL-1 $\beta$ and TNF $\alpha$ were from Genzyme. Mouse anti-human IFN $\gamma$ polyclonal neutralizing antibodies were also from Genzyme.

Immunocytochemical staining. The epithelial nature of primary and cultured HAEC was confirmed by immunocytochemical staining. Airway epithelial cells freshly obtained from bronchial brushing or in culture were fixed in $4 \%$ formaldehyde and transferred into $2.5 \%$ agarose. The agarose specimen was dehydrated and embedded in paraffin. Microsections were prepared for immunocytochemical staining using a biotin-streptavidin detection system with diaminobenzidine (Sigma Chemical Co., St. Louis, MO) as the chromogen as previously described (15). Mouse anti-human cytokeratin mAb RCK102 (1:25; Organon Teknika, Boxtel, Holland), NCL5D3 (1:100; Organon Teknika), and 34ßE12 (1:100; Dako Corp., Carpinteria, CA) were used to confirm epithelial phenotype. Immunostaining for vimentin using mouse anti-human vimentin mAb (1:100; Organon Teknika) was performed to exclude contamination by fibroblasts; anti-human cluster of differentiation (CD)3 mAb (1:200; Dako, Glostrup, Denmark) to exclude lymphocyte contamination; and anti-human CD68 mAb (1:100; Dako) to exclude macrophage contamination in cultures. After incubation with primary antibody, slides were washed in PBS and incubated with biotinylated rabbit anti-mouse antibody (1: 500; Dako) for 30 min at room temperature, rinsed again with PBS, and incubated with diaminobenzidine/imidazole (1:1) for $5 \mathrm{~min}$. Subsequently, the slides were counterstained with Mayers' hematoxylin, dehydrated, cleared in xylene, and mounted with Entellan (Merck, Darmstadt, Germany).

RNA extraction and Northern analysis. Total RNA was extracted and evaluated by Northern analyses as previously described using a ${ }^{32} \mathrm{P}$-labeled 1.9-kb iNOS cDNA probe (pCCF21) (4) or as a control, $1.5 \mathrm{~kb} 18 \mathrm{~S}$ cDNA probe (HHCSA65; American Type Culture Collection). Quantitation of iNOS mRNA relative to $18 \mathrm{~S}$ was accomplished using a PhosphorImager (Molecular Dynamics, Inc., Sunnyvale, CA).

Cytoplasmic extract and whole cell extract (WCE) preparation and EMSA. WCE from untreated or cytokine-treated HAEC and other cell lines were prepared by a modification of a previously described method (16). Adherent cells were harvested by a cell lifter, and the cell suspensions were centrifuged and washed with PBS, and resuspended in ice-cold low-salt buffer (10 mM Hepes, $\mathrm{pH} 7.9,1.5 \mathrm{mM}$ $\mathrm{MgCl}_{2}, 10 \mathrm{mM} \mathrm{KCl}, 0.5 \mathrm{mM}$ PMSF, $0.5 \mathrm{mM}$ DTT). After a 5-min incubation on ice, cells were washed in the same buffer, then pelleted. A volume of high-salt extraction buffer equal to the volume of cell pellet was added ( $20 \mathrm{mM}$ Hepes, $\mathrm{pH} 7.9,25 \%$ glycerol, $0.42 \mathrm{M} \mathrm{NaCl}$, $1.5 \mathrm{mM} \mathrm{MgCl}_{2}, 0.2 \mathrm{mM}$ EDTA, $0.5 \mathrm{mM}$ PMSF, $0.5 \mathrm{mM}$ DTT, $5 \mu \mathrm{g} / \mathrm{ml}$ leupeptin, and $2 \mu \mathrm{g} / \mathrm{ml}$ aprotinin) and the mixture placed on ice for 30 min. WCE were clarified by centrifugation at $12,000 \mathrm{~g}$ for $20 \mathrm{~min}$ at $4^{\circ} \mathrm{C}$. The protein concentration was measured by bicinchoninic (BCA) protein assay (Pierce, Rockford, IL).

For EMSA experiments, the IFN $\gamma$ activation site oligonucleotide (GAS) (5'-tcgaGCCTGATTTCCCCGAAATGACGGC-3') corresponding to human IFN regulatory factor-1 (IRF-1) promoter from basepairs (bp) -130 to -106 sequence relative to transcription start point (17), or the IL-4 response element (IL-4GAS) (5'-GATTTTCCCAGAAAAGGAAC-3') corresponding to the human high-affinity $\mathrm{IgG}$ receptor $(\mathrm{Fc} \gamma \mathrm{RI})$ gene promoter from -33 to -14 bp (18) was used. These synthetic oligonucleotides were either end-labeled with $\left[{ }^{32} \mathrm{P}\right] \gamma \mathrm{ATP}$ by polynucleotide kinase or fill-in labeled with $\left[{ }^{32} \mathrm{P}\right] \alpha \mathrm{dCTP}$ by Klenow. For IRF-1GAS and IL-4GAS binding complex detection, ${ }^{32} \mathrm{P}$-labeled oligonucleotide $(0.2 \mathrm{ng})$ was incubated with $5 \mu \mathrm{g}$ of WCE protein in $24 \mu \mathrm{l}$ final reaction volume containing $20 \mathrm{mM}$ Hepes, $\mathrm{pH} 7.9,10 \%$ glycerol, $60 \mathrm{mM} \mathrm{NaCl}, 5 \mathrm{mM} \mathrm{MgCl}_{2}, 4 \mathrm{mM}$ Tris- $\mathrm{HCl}, 1 \mathrm{mM}$ DTT, $0.6 \mathrm{mM}$ EDTA, and $2 \mu \mathrm{g}$ (for IL-4GAS binding reaction) or $4 \mu \mathrm{g}$ (for IRF-1GAS binding reaction) of polydeoxyinosinic: polydeoxycytidylic acid (Amersham, Arlington Heights, IL). The binding reaction mixture was incubated at room temperature for 15 min before electrophoresis on 6\% acrylamide gels (acrylamide/ bisacrylamide ratio $29: 1$ ) in $0.4 \times$ TBE ( $36 \mathrm{mM}$ Tris, $36 \mathrm{mM}$ boric acid, $8 \mu \mathrm{M}$ EDTA). The gels were dried and analyzed by autoradiography. To demonstrate specificity of binding, competition was performed by adding unlabeled oligonucleotide at 100 times molar excess of ${ }^{32} \mathrm{P}$-labeled oligonucleotide probe in the binding reaction. To specifically identify STAT (signal transducers and activators of transcription) proteins, $2 \mu \mathrm{g}$ of rabbit anti-STAT1 polyclonal antibodies (19) or rabbit anti-STAT6 polyclonal antibodies (Santa Cruz Biotechnology, Santa Cruz, CA) was added to the binding reaction mix and incubated for $30 \mathrm{~min}$ at $4^{\circ} \mathrm{C}$ before adding the ${ }^{32} \mathrm{P}$-labeled oligonucleotide.

Measurement of NO production by chemiluminescence. The NO production by cultured cells was measured using a nitric oxide analyzer (NOA; Sievers, Boulder, CO). Nitrate and nitrite present in overlying tissue culture media $(4 \mu \mathrm{l})$ were converted to NO by a saturated solution of $\mathrm{VCl}_{3}$ in $0.8 \mathrm{M} \mathrm{HCl}$, and the $\mathrm{NO}$ detected based on a 
gas-phase chemiluminescent reaction between NO and ozone (20). Nitrite and nitrate standards were also tested and displayed linearity between 1 and $125 \mu \mathrm{M}\left(r^{2} \geq 0.995\right.$ for all experiments) and were detected with equal efficiency $(<15 \%$ difference in detection at any concentration). Nitrite and nitrate levels were determined by interpolation from the known standard curves.

Quantitation of cytokine levels and IFN $\gamma$ activity. IFN $\gamma$ and IL-4 levels in BAL were determined using an enhanced quantitative enzyme-linked immunosorbent assay with sensitivities of $2 \mathrm{pg} / \mathrm{ml}$ and no detectable cross-reactivities (ELISA) (Endogen, Inc., Boston, MA). Recombinant human IFN $\gamma$ and IL-4 were used as standards in the ELISAs. Soluble and cell-associated, CD23 levels in cytokine-stimulated cells were quantitatively determined by enzyme immunoassay using the CD23 test kit (T Cell Diagnostics, Woburn, MA). IFN $\gamma$ biologic activity in overlying tissue culture media was quantitated using an antiviral cytopathic effect inhibition assay with encephalomyocarditis virus in a human amnion epithelial cell line, WISH (PBL Biomedical Laboratories, West Caldwell, NJ) (21).

\section{Results}

Evaluation of cellular characteristics. Cultured HAEC isolated from bronchoscopic brushing and postmortem airways were strongly stained using the mouse anti-human cytokeratin mAbs NCL5D3, RCK102, and 34ßE12, with cytokeratin posi-
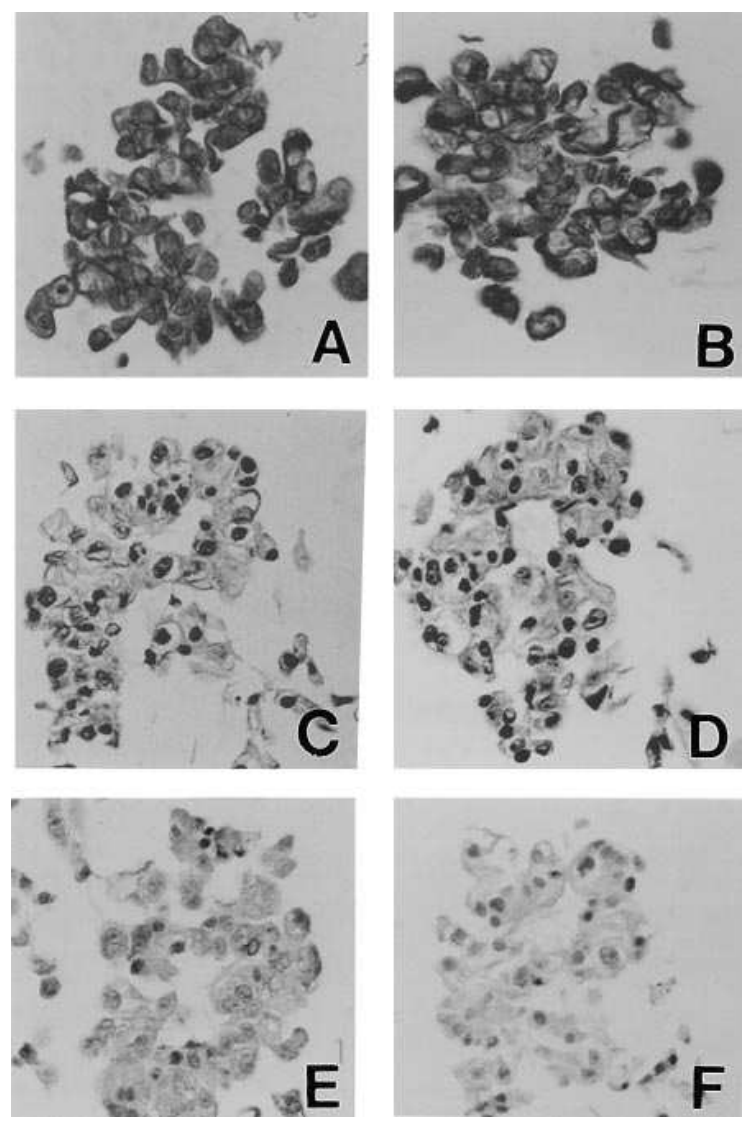

Figure 1. Immunohistochemistry of HAEC in culture. $(A)$ Immunohistochemistry using anti-human cytokeratin mAb (34ßE12) showed strong staining in cytoplasm of cultured HAEC. (B) Similarly, staining was observed with other anti-human cytokeratin mAbs (RCK102). No significant immunostaining was observed in HAEC with $(C)$ anti-human vimentin $\mathrm{mAb},(D)$ anti-CD3 $\mathrm{mAb}$, or $(E)$ antiCD68 mAb. $(F)$ Negative control using no primary antibody had no staining detectable. $\times 460$. tivity similar to freshly obtained airway epithelial cells (Fig. 1). No significant immunostaining was found with mouse antihuman vimentin $\mathrm{mAb}$, anti-CD3, or anti-CD68, excluding contamination of cultures by fibroblasts, lymphocytes, or macrophages. Strong immunoreactivity for cytokeratins was also obtained for the transformed bronchial epithelial cell line, BEAS2B, however BEAS2B also had faint positive staining for vimentin (not shown).

iNOS gene induction in respiratory epithelial cells. We have shown previously that iNOS gene expression in human airway epithelial cells was lost within $24 \mathrm{~h}$ of culture (4). To investigate the regulatory mechanisms of iNOS expression in airway epithelium, the responses of respiratory epithelial cells to various cytokines previously shown to influence iNOS gene expression (7-11) were evaluated.
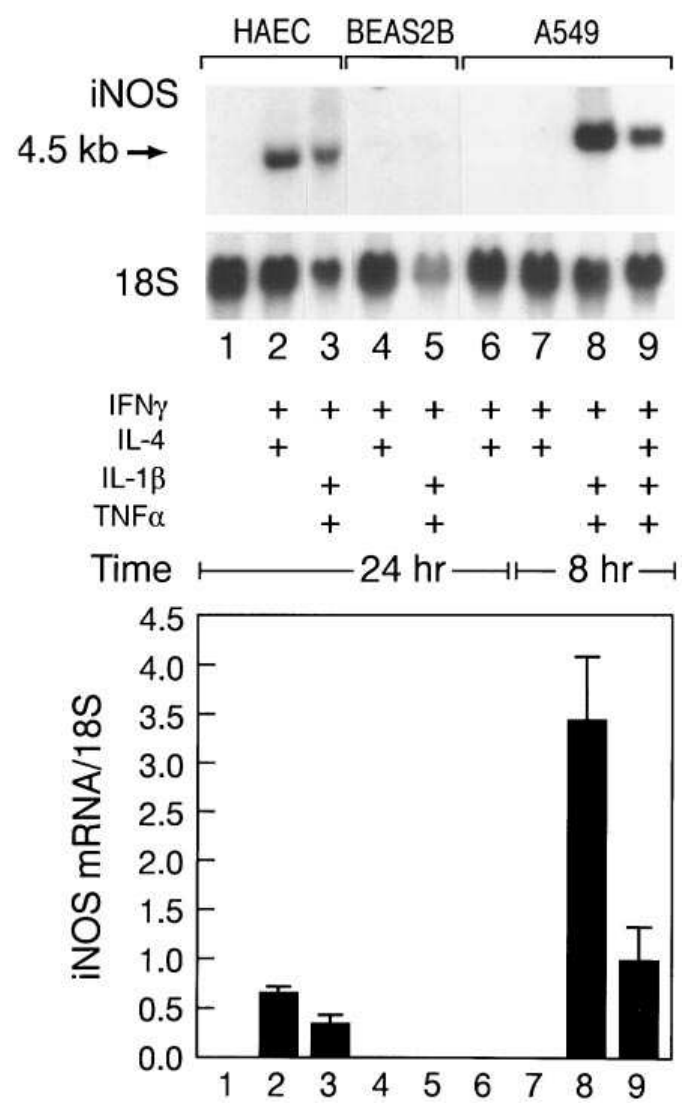

Figure 2. iNOS gene induction in respiratory epithelial cells in vitro. Primary HAEC (lanes 1-3), transformed human bronchial epithelial cell line (BEAS2B, lanes 4 and 5), and lung adenocarcinoma epithelial cell line (A549, lanes 6-9) were cultured in the presence of various combinations of cytokines for 8 or $24 \mathrm{~h}$. Northern analyses of RNA ( $5 \mu \mathrm{g}$ total RNA/lane) were performed using ${ }^{32} \mathrm{P}$-labeled human iNOS cDNA (pCCF21), and as a control, 18S cDNA (HHCSA65). Unstimulated HAEC in culture did not express iNOS (lane 1). However, the 4.5-kb iNOS mRNA was detected in HAEC and A549 cells stimulated by IL-1 $\beta$, TNF $\alpha$, and IFN $\gamma$ (lanes 3 and 8 ). In contrast, cytokine-stimulated and unstimulated BEAS2B did not express iNOS mRNA at levels detectable by Northern analysis (lanes 4 and 5). IL-4 inhibited iNOS mRNA induction in cytokine-stimulated A549 (lane 9), but did not inhibit iNOS mRNA induction in HAEC (lane 2). The Northern blot shown is representative of at least three experiments for each condition yielding similar results. Relative units of iNOS mRNA/18S is summarized in the graph, with mean values and SD demonstrated. 
Induction of iNOS mRNA was seen in HAEC after a 24-h culture with IFN $\gamma$ alone, or with the combination of IFN $\gamma$ and IL-4, or with IFN $\gamma$, IL-1 $\beta$, and TNF $\alpha$. Although IFN $\gamma$, IL-1 $\beta$, and $\mathrm{TNF} \alpha$ induced iNOS mRNA expression as previously described in HAEC (22), the levels of iNOS mRNA were less than levels induced by IFN $\gamma$ and IL-4 (Fig. 2). Subsequently, HAEC were cultured with varying doses of IFN $\gamma$ and/or IL-4 for $24 \mathrm{~h}$ (Fig. $3 \mathrm{~A}$ ). Although IFN $\gamma$ alone induced iNOS mRNA in HAEC, iNOS mRNA levels were increased twofold by addition of IL-4, 10 or $100 \mathrm{ng} / \mathrm{ml}$. However, IL-4 alone at 10 or $100 \mathrm{ng} / \mathrm{ml}$ did not induce iNOS expression, indicating potentiation of IFN $\gamma$ induction of iNOS by IL-4 (iNOS mRNA/18S relative units: IFN $\gamma[100 \mathrm{U} / \mathrm{ml}]$ 0.14 \pm 0.09 ; IL-4 [100 ng/ml $] 0$; IFN $\gamma[100 \mathrm{U} / \mathrm{ml}]$ and IL-4 [100 ng/ml] 0.37 $\pm 0.14 ; \mathrm{IFN} \gamma[100$ $\mathrm{U} / \mathrm{ml}]$ and IL-4 [10 ng/ml] 0.25 \pm 0.06 ; mean $\pm \mathrm{SD}, n=2-5 \mathrm{ex}-$ periments for each dose). Therefore, $100 \mathrm{U} / \mathrm{ml} \mathrm{IFN} \gamma$ combined with 10 or $100 \mathrm{ng} / \mathrm{ml} \mathrm{IL-4}$ as indicated in the text was used for maximal iNOS induction in subsequent experiments.

Similar to previous reports, iNOS mRNA was induced in A549 cells by a combination of cytokines (22-24). IFN $\gamma$ and IL-1 $\beta$ induced iNOS, but addition of TNF $\alpha$ to the IL-1 $\beta$ and IFN $\gamma$ further increased iNOS mRNA levels in A549 cells over threefold, with peak iNOS expression at $8 \mathrm{~h}$ (Fig. 2). In contrast to the HAEC, we found that IL-4 consistently decreased IFN $\gamma$-, IL-1 $\beta$-, and TNF $\alpha$-induced iNOS mRNA by over 2.5fold in A549 cells (Fig. 2). In contrast to the A549 and HAEC, iNOS mRNA could not be induced by varying combination and doses of IFN $\gamma$, IL-4, IL-1 $\beta$, and/or TNF $\alpha$ in the transformed human airway epithelial cell line BEAS2B at levels detectable by Northern analysis (Fig. 2). Previous studies have reported that corticosteroids may reduce iNOS mRNA expression $(3,23,24)$. Thus, BEAS2B and HAEC were also cultured in LHC8 media without phenol red, a weak estrogen, and without hydrocortisone additive. Despite this, no differences in the pattern of iNOS mRNA induction were found in the HAEC or BEAS2B.

Prolonged $i N O S$ expression in human airway epithelial cells in response to a single stimulation event. iNOS mRNA levels in
HAEC were barely detectable at $8 \mathrm{~h}$ and maximal by $24 \mathrm{~h}$ after stimulation with IFN $\gamma$ and IL-4. However, the iNOS expression was unusually prolonged with iNOS mRNA present at $4 \mathrm{~d}$ and even $6 \mathrm{~d}$ after a single initiating stimulation with IFN $y$ and IL-4 (Fig. 3 B). As previously reported, iNOS mRNA expression in A549 cells peaked at $8 \mathrm{~h}$ after stimulation with IFN $\gamma$, IL-1 $\beta$, and TNF $\alpha$ and decreased by $48 \mathrm{~h}$ (22).

Lack of effect on iNOS mRNA expression by inhibition of NOS activity. NOS activity was detectable in HAEC in culture by measure of nitrite/nitrate levels in the overlying tissue culture media of cells stimulated with IL-4 and IFNy over time in culture (mean \pm SD $\mu \mathrm{M}$ nitrite/nitrate in media of IL-4 and IFN $\gamma$ stimulated cells for $48 \mathrm{~h} 24.5 \pm 3.5$; and $7 \mathrm{~d} 57 \pm 6, n=4)$. To determine if NO synthesized by NOS was affecting iNOS gene expression, IFN $\gamma$ - and IL-4-induced iNOS mRNA in HAEC was evaluated by Northern analysis in the presence of the NOS inhibitor, $N^{\mathrm{G}}$-monomethyl-L-arginine (L-NMMA) $(200 \mu \mathrm{M})$. Although L-NMMA inhibited the cytokine-induced NO production in overlying tissue culture media, the levels of iNOS mRNA induced by IFN $\gamma$ and IL-4 in the presence of L-NMMA were $104 \pm 3 \%(n=2)$ of iNOS mRNA levels in HAEC stimulated by IL-4 and IFN $\gamma$ for $24 \mathrm{~h}$.

IL-4 prolongs iNOS $m R N A$ half-life in HAEC. To determine if prolonged iNOS mRNA levels in HAEC after IFNy and IL-4 stimulation were due to increased stability of the iNOS mRNA, the half-life of iNOS mRNA in HAEC stimulated with IFN $\gamma$ and IL-4 was compared with A549 cells stimulated with IFN $\gamma$, IL-1 $\beta$, and TNF $\alpha$. iNOS mRNA was maximally induced in HAEC by $24 \mathrm{~h}$ of culture with IFN $\gamma(100 \mathrm{U} / \mathrm{ml})$ and IL-4 $(100 \mathrm{ng} / \mathrm{ml})$ or IFN $\gamma$ alone $(1,000 \mathrm{U} / \mathrm{ml})$, and in A549 cells by $8 \mathrm{~h}$ of culture with IFNy $(100 \mathrm{U} / \mathrm{ml}), \mathrm{IL}-1 \beta(10 \mathrm{U} / \mathrm{ml})$, and TNF $\alpha$ (10 ng/ml). New RNA synthesis was then blocked by adding actinomycin D $(3 \mu \mathrm{g} / \mathrm{ml})$ to cultures. Cells were harvested after different time intervals to determine iNOS mRNA levels by Northern analysis. The half-life of iNOS mRNA in IFN $\gamma$-, IL-4-stimulated HAEC $(6.6 \pm 0.5 \mathrm{~h})$ was longer than IFN $\gamma$ stimulated HAEC $(3.7 \pm 0.6 \mathrm{~h})$ or IFN $\gamma$-, IL-1 $\beta-$, TNF $\alpha$-stimulated A549 cell line ( $3.8 \pm 0.5$ h) (Fig. 4). Thus, IL-4 prolonged

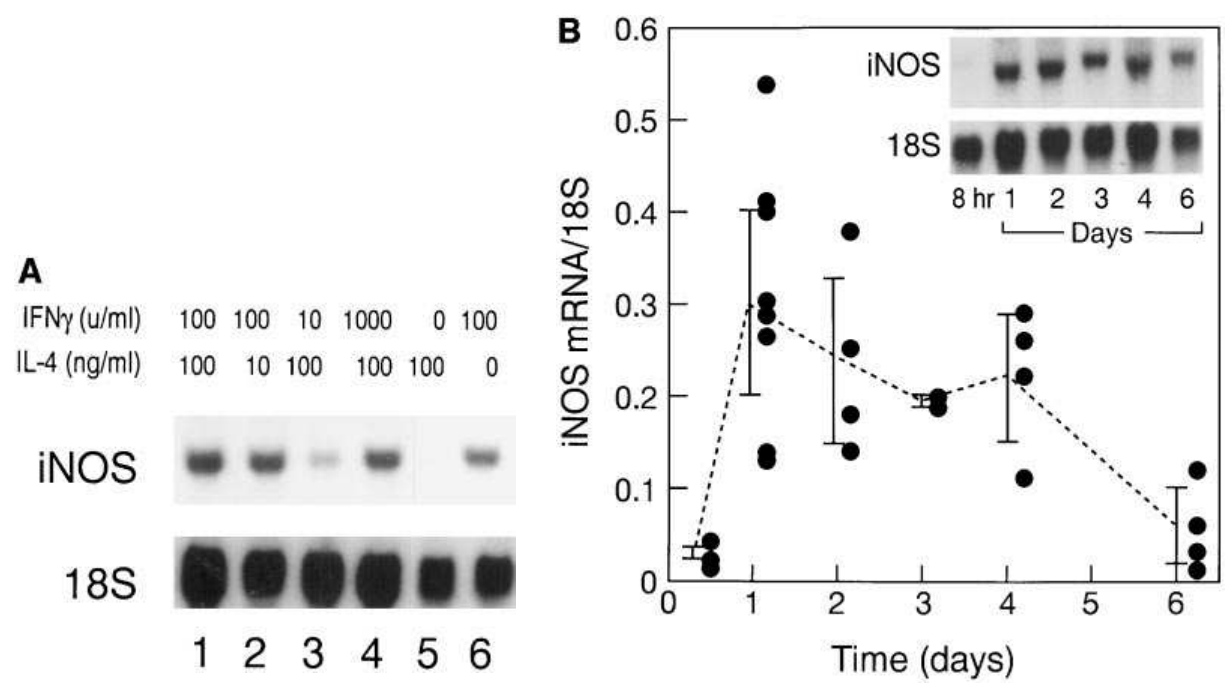

Figure 3. (A) IL-4 potentiates IFN $\gamma$ induction of iNOS mRNA expression in HAEC. HAEC were cultured in the presence of $0-1,000 \mathrm{U} / \mathrm{ml} \mathrm{IFN} \gamma$ and/or $0-100 \mathrm{ng} / \mathrm{ml} \mathrm{IL}-4$ for $24 \mathrm{~h}$. Northern analyses of RNA ( $5 \mu \mathrm{g}$ total RNA/ lane) demonstrate that IFN $\gamma$ alone was effective for induction of iNOS mRNA (lane 6), but IL-4 alone was unable to induce iNOS (lane 5). However, the addition of IL-4 (10 or $100 \mathrm{ng} / \mathrm{ml})$ to IFN $\gamma(100 \mathrm{U} / \mathrm{ml})$ led to 1.7 - and 2-fold higher levels of iNOS mRNA than IFN $\gamma$ alone (lanes 1 and 4). The Northern blot shown is representative of two to five experiments for each dose. $(B)$ Prolonged time course of iNOS mRNA expression in HAEC induced by IFN $\gamma$ and IL-4. HAEC were cultured in the presence of IFN $\gamma(100 \mathrm{U} / \mathrm{ml})$ and IL-4 $(10 \mathrm{ng} / \mathrm{ml})$ for times of $8 \mathrm{~h}$ to $6 \mathrm{~d}$. (Inset) The representative Northern blot of the time course of iNOS induction (5 $\mu \mathrm{g}$ of total RNA/lane) demonstrates induction of iNOS mRNA is barely detectable at $8 \mathrm{~h}$, maximal at 1-4 d, and is still clearly detectable at $6 \mathrm{~d}$ after cytokine stimulation. Relative units of iNOS mRNA/18S of all times evaluated is summarized in the graph, with mean values connected by the dashed line and SD demonstrated. 

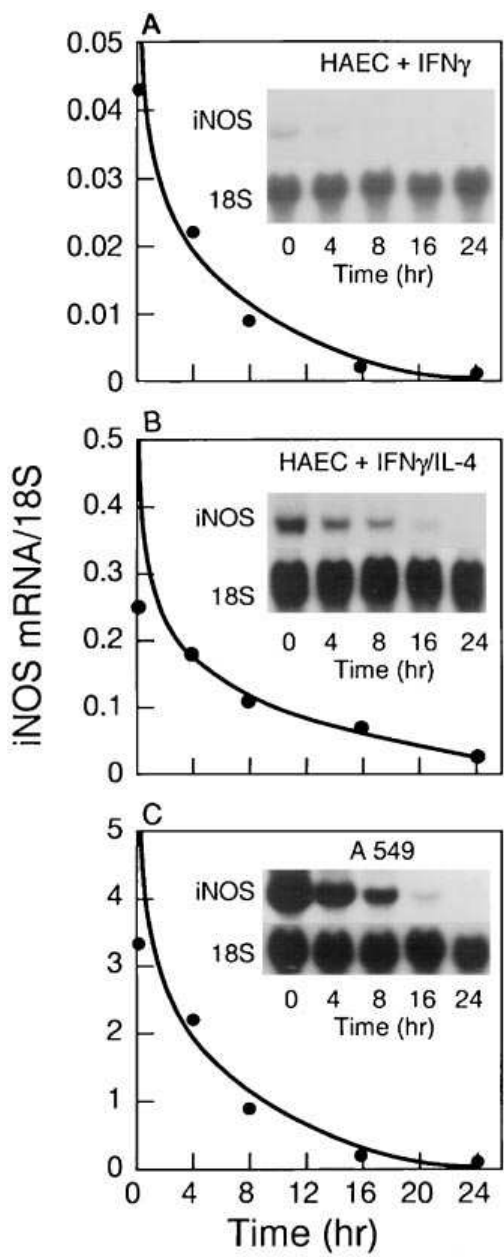

Figure 4. Half-life of iNOS mRNA in HAEC and A549. (A) HAEC were cultured in the presence of IFN $\gamma$ alone $(1,000 \mathrm{U} / \mathrm{ml})$ for $24 \mathrm{~h}$, (B) $\operatorname{IFN} \gamma(100 \mathrm{U} / \mathrm{ml})$ and IL-4 $(10 \mathrm{ng} / \mathrm{ml})$ for $24 \mathrm{~h}$, and $(C)$ A549 were cultured with IFN $\gamma(100$ $\mathrm{U} / \mathrm{ml})$, IL-1 $\beta(10 \mathrm{U} / \mathrm{ml})$, and TNF $\alpha(10 \mathrm{ng} / \mathrm{ml})$ for $8 \mathrm{~h}$. Cells were collected at this time (time 0 ) and at indicated times (h) after addition of actinomycin D $(3 \mu \mathrm{g} / \mathrm{ml})$ to block mRNA synthesis. Total RNA from cells at each time were subjected to Northern analysis $(5 \mu \mathrm{g} /$ lane $)$ with ${ }^{32} \mathrm{P}$-labeled iNOS cDNA and 18S cDNA. The representative Northern blots (insets) demonstrate loss of iNOS mRNA after addition of actinomycin D. The graphic representations of the mRNA decay data of iNOS mRNA/18S were fit by semilogarithmic equations using Cricket Graph computer software (HAEC [IFN $\gamma]$

curve $r=0.959$, HAEC [IFN $\gamma /$ IL-4] curve $r=0.994$, A549 curve $r=0.968)$, and used to determine iNOS mRNA half-life for HAEC in the presence of IFN $\gamma$ alone $(3.7 \pm 0.6 \mathrm{~h}, n=2)$, IFN $\gamma$ and IL-4 $(6.6 \pm 0.5 \mathrm{~h}, n=4)$, and A549 (3.8 $\pm 0.5 \mathrm{~h}, n=2)$.

the half-life of the iNOS mRNA in HAEC, suggesting this is one mechanism for the potentiation of the IFN $\gamma$-induced iNOS mRNA signal by IL-4. However, continuing iNOS expression in HAEC for $6 \mathrm{~d}$ after cytokine stimulation indicated that the prolonged expression was dependent upon continuous iNOS mRNA induction in addition to mRNA stabilization.

Soluble mediators maintain iNOS expression. While iNOS mRNA was present up to $6 \mathrm{~d}$ after a single initial stimulation with IFN $\gamma$ and IL-4, removal of the overlying tissue culture media and addition of fresh media at $6 \mathrm{~d}$ resulted in a decrease in iNOS mRNA by $24 \mathrm{~h}$ after media change, as compared with cells that continued to be cultured in the original media (Fig. 5). Removal of overlying tissue culture media from HAEC and addition of fresh media decreased iNOS expression by $>90 \%$. Importantly, transfer of the 6-d tissue culture media (referred to as conditioned media) to other HAEC induced iNOS mRNA expression (Fig. 5). However, transfer of conditioned media to A549 or BEAS2B cell lines did not induce iNOS expression at either 8 or $24 \mathrm{~h}$ (Fig. 5).

Using an antiviral cytopathic effect inhibition assay with encephalomyocarditis virus in a human amnion epithelial cell line, we determined that $6 \mathrm{~d}$ after adding $100 \mathrm{U} / \mathrm{ml} \mathrm{IFN} \gamma$ to

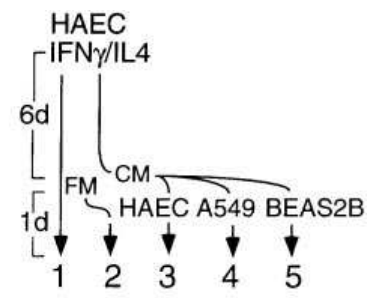

Figure 5. Soluble mediator(s) lead to iNOS expression in HAEC. HAEC were cultured in IFN $\gamma(100 \mathrm{U} / \mathrm{ml})$ and IL-4 $(10 \mathrm{ng} / \mathrm{ml})$ for $7 \mathrm{~d}$ (lane 1$)$ or $6 \mathrm{~d}$ after which overlying tissue culture media (conditioned media, $C M$ ) was removed and the HAEC cultured for $24 \mathrm{~h}$ more in fresh media (FM) without IL-4/IFN $\gamma$ (lane 2). The 6-d conditioned media was transferred to HAEC (lane 3), A549 (lane 4), or BEAS2B (lane 5) and cultured for $24 \mathrm{~h}$. Total RNA from cells were extracted and levels of iNOS mRNA, and as a control $18 \mathrm{~S}$ RNA, were assessed by Northern analysis ( $5 \mu \mathrm{g}$ total RNA/lane). HAEC cultured in the presence of IL- 4 and IFN $\gamma$ for $7 \mathrm{~d}$ had persistent iNOS mRNA expression (lane 1), while HAEC cultured in parallel for $6 \mathrm{~d}$ had diminished iNOS mRNA within $24 \mathrm{~h}$ of fresh media addition (lane 2). Exposure of other cells to the 6-d conditioned media demonstrated that iNOS mRNA was induced in HAEC (lane 3) but not in A549 (lane 4) or BEAS2B (lane 5). Similar results were obtained in three separate experiments.

HAEC that $<10 \%$ of the IFN $\gamma$ biological activity remained in the overlying tissue culture media $(<10 \mathrm{U} / \mathrm{ml})$. To investigate if the transferable mediator(s) in the conditioned media leading to induction of iNOS mRNA was due to the small amount of remaining IFN $\gamma$ activity, the conditioned media were treated with mouse anti-human IFN $\gamma$ neutralizing $\mathrm{mAb}$, or mouse nonimmune IgG before transfer of the conditioned media to HAEC. As a test of the effectiveness of the antiIFN $\gamma \mathrm{Ab}$ for neutralization of IFN $\gamma$ activity, the ability of IFN $\gamma$ neutralizing $\mathrm{Ab}$ to inhibit iNOS mRNA induction in A549 cells by IFN $\gamma$ and IL-1 $\beta$ was also evaluated. The iNOS mRNA expression in A549 cell line induced by IFN $\gamma$ and IL$1 \beta$ containing IFN $\gamma$ neutralizing $\mathrm{Ab}$ was $11 \%$ of the iNOS level in A549 cell line induced by IFN $\gamma$ and IL-1 $\beta$ containing nonimmune IgG. In contrast in HAEC, iNOS mRNA induced by the conditioned media containing IFN $\gamma$ neutralizing $\mathrm{Ab}$ was similar to levels induced by conditioned media containing nonimmune IgG (iNOS mRNA/18S relative units: conditioned media + nonimmune $\mathrm{IgG} 0.11 \pm 0.03$, conditioned media + IFN $\gamma$ neutralizing $\mathrm{Ab} 0.10 \pm 0.03$, mean $\pm \mathrm{SD}, n=3$ ). Importantly, levels of iNOS mRNA induction by direct addition of IFN $\gamma$ at $10 \mathrm{U} / \mathrm{ml}$ (Fig. $3 A$, lane 3 ) were markedly lower than levels of iNOS mRNA induced by conditioned media. Therefore, it is unlikely that IFN $\gamma$ is primarily contributing to the induction of iNOS by conditioned media.

Protein synthesis-dependent mediator(s) required for iNOS $m R N A$ induction in HAEC. To determine if the mediators leading to transferable and prolonged iNOS expression in HAEC were dependent on new protein synthesis, HAEC were stimulated with IFN $\gamma$ and IL-4 in the presence of cycloheximide $(10 \mu \mathrm{g} / \mathrm{ml})$ and the levels of iNOS mRNA were analyzed by Northern analysis. In the positive control, iNOS mRNA was induced by stimulating with IFN $\gamma$ and IL-4 for $24 \mathrm{~h}$ (Fig. $6 \mathrm{~A}$ ). In the presence of cycloheximide, iNOS mRNA levels in HAEC stimulated with IFN $\gamma$ and IL-4 were decreased to $38 \pm 3 \%$ of the positive control (Fig. $6 A$ ). Cycloheximide alone 


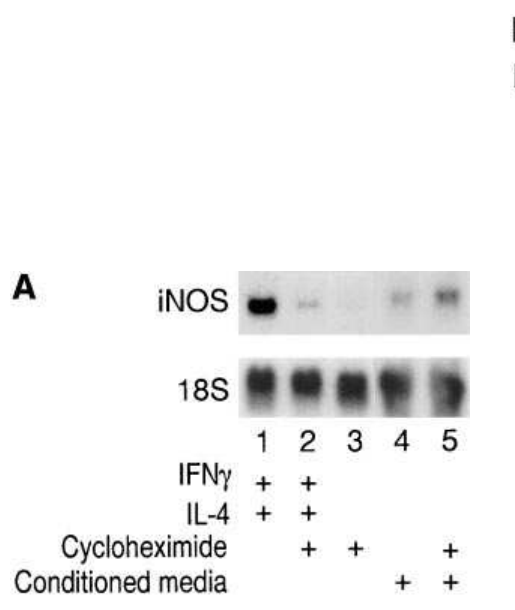

B

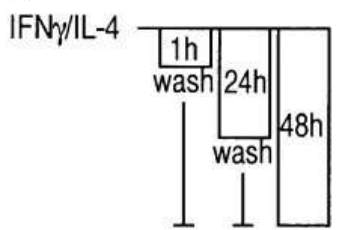

iNOS

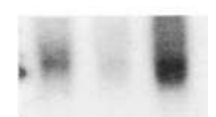

$18 S$

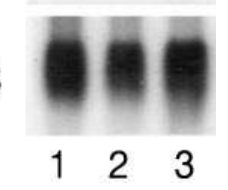

Figure 6. (A) Protein synthesis-dependent mediator(s) required for iNOS induction in HAEC. HAEC were cultured under the following conditions for $24 \mathrm{~h}$ : lane 1, with IFN $\gamma(100 \mathrm{U} / \mathrm{ml})$ and IL-4 $(10 \mathrm{ng} / \mathrm{ml})$; lane 2 , as in lane 1 with $10 \mu \mathrm{g} / \mathrm{ml}$ of cycloheximide; lane $3,10 \mu \mathrm{g} / \mathrm{ml}$ cycloheximide; lane 4, $6 \mathrm{~d}$ conditioned media; lane $5,6 \mathrm{~d}$ conditioned media containing $10 \mu \mathrm{g} / \mathrm{ml}$ cycloheximide. Representative Northern analysis shows iNOS mRNA induction with IL-4/IFN $\gamma$ (lane 1) was inhibited by the protein synthesis inhibitor cycloheximide (lane 2) although cycloheximide alone has no detectable effect on iNOS expression (lane 3). While conditioned media induced iNOS mRNA (lane 4 ), protein synthesis inhibition did not decrease conditioned mediainduced iNOS expression. Similar results were obtained in two separate experiments. $(B)$ Dependence on early synthesis of mediator(s) for IFN $\gamma / \mathrm{IL}-4$-induced iNOS expression in HAEC. HAEC were cultured with IFN $\gamma(100 \mathrm{U} / \mathrm{ml})$ and IL-4 $(10 \mathrm{ng} / \mathrm{ml})$ for $1 \mathrm{~h}$ (lane 1$)$ or $24 \mathrm{~h}$ (lane 2), then media containing IFN $\gamma / \mathrm{IL}-4$ removed, and cells washed and cultured in fresh media without cytokines for 47 and $24 \mathrm{~h}$, respectively. HAEC were also cultured in the presence of IFN $\gamma / \mathrm{IL}-4$ for $48 \mathrm{~h}$ (lane 3). Northern analysis of total RNA from HAEC $(5 \mu \mathrm{g} /$ lane) was performed with ${ }^{32} \mathrm{P}$-labeled iNOS cDNA and $18 \mathrm{~S}$ cDNA. The 1-h wash-off (lane 1) had similar levels of iNOS mRNA expression to continuous culture with IFN $\gamma / \mathrm{IL}-4$ (lane 3 ). However, $24 \mathrm{~h}$ of wash-off (lane 2) resulted in marked reduction in iNOS mRNA levels compared with $1 \mathrm{~h}$ of wash-off or continuous culture with IFN $\gamma / \mathrm{IL}-4$. Similar results were obtained in two separate experiments.

had no effect on unstimulated HAEC iNOS mRNA levels (Fig. 6 A). In contrast, induction of iNOS mRNA in HAEC by the conditioned media was not decreased by the presence of cycloheximide, with iNOS mRNA levels in HAEC stimulated with conditioned media in the presence of cycloheximide $150 \pm 30 \%$ of iNOS levels in HAEC stimulated with conditioned media alone (Fig. $6 \mathrm{~A}$ ). These results indicate that the induction of iNOS mRNA by IFN $\gamma$ and IL-4 in HAEC required new protein synthesis-dependent mediator(s).

To confirm this, wash-off experiments were performed. After a 1-h incubation of HAEC with IFN $\gamma$ and IL-4, the cells were vigorously washed with Hepes buffered saline and cultured in fresh media without cytokines for $2 \mathrm{~d}$. Northern analysis showed that iNOS expression in the HAEC exposed to IFN $\gamma$ and IL- 4 for $1 \mathrm{~h}$ was $90 \pm 10 \%$ of the iNOS mRNA levels in HAEC cultured with IFN $\gamma$ and IL-4 continuously for $2 \mathrm{~d}$ (Fig. 6 B). However, when HAEC were stimulated with IFNy and IL-4 for $24 \mathrm{~h}$, followed by vigorous wash with Hepes buffered saline, and then cultured in fresh media without cytokines for an additional $24 \mathrm{~h}$ (for a total of $2 \mathrm{~d}$ after the initial addition of cytokines), the levels of iNOS mRNA in the HAEC were markedly decreased to $15 \pm 5 \%$ of the positive control of HAEC cultured for $2 \mathrm{~d}$ continuously with IFN $\gamma$ and IL-4 (Fig. 6 B). These results indicated that IFN $\gamma$ - and IL-4-induced iNOS mRNA expression in HAEC was dependent upon new mediator synthesis and secretion. Furthermore, the majority of the mediator(s) synthesis or secretion appears to occur in the time periods from 1 to $24 \mathrm{~h}$ after IFN $\gamma$ and IL-4 stimulation, but is relatively stable and transferable in the conditioned media for up to $6 \mathrm{~d}$. These results demonstrate that continuous synthesis of mediator(s) occurs up to $24 \mathrm{~h}$ and is protein synthesis dependent.

$E M S A$. IFN $\gamma$ has been identified as a key factor activating iNOS gene transcription in various cells through the Janus kinase (JAK)-STAT1 signal transduction pathways (19). Further, the interferon inducible gene, IRF-1 has also been identified as essential for iNOS activation in murine macrophages (25). To investigate the involvement of the JAK-STAT pathway in our system, EMSA with WCE from HAEC stimulated with IFN $\gamma(100 \mathrm{U} / \mathrm{ml})$ and IL-4 $(10 \mathrm{ng} / \mathrm{ml})$ for $15 \mathrm{~min}, 8 \mathrm{~h}$, and $6 \mathrm{~d}$ were performed. The results (Fig. $7 A$ ) indicated that a single major binding complex was induced using the GAS element from the human IRF-1 promoter (19). This binding complex was confirmed to contain STAT1 by supershifting with anti-human STAT1 antibodies (Fig. $7 A$ ). In contrast, no STAT1 containing complex was detected in nonstimulated HAEC. The STAT1 complex was detected at $6 \mathrm{~d}$ culture after IFN $\gamma$ and IL-4 stimulation, although the level of activation was much lower than that observed at $15 \mathrm{~min}$ or $8 \mathrm{~h}$ after stimulation (Fig. 7 C).

The IL-4 signal transduction pathway through STAT6 was also investigated by EMSA (Fig. 7 B) using the IL-4 response element (IL-4GAS). A STAT6-containing complex was absent in WCE of nonstimulated HAEC. WCE from HAEC directly stimulated in culture with IFN $\gamma(100 \mathrm{U} / \mathrm{ml})$ and IL-4 (10 $\mathrm{ng} / \mathrm{ml}$ ) for $15 \mathrm{~min}, 8 \mathrm{~h}$, or $6 \mathrm{~d}$ demonstrated a binding complex consisting of two bands. The upper band was similar in mobility to the positive control for STAT6 activation in THP1 stimulated with IL-4. Incubation with anti-STAT6 antibodies shifted the upper band, while anti-STAT1 antibodies shifted the lower band. Further, while both complexes were competed by unlabeled IL-4GAS, only the lower band was competed by unlabeled IRF-1GAS indicating a preference of binding of STAT1 to the IRF-1GAS element (Fig. 7 B). In addition, IL-4 alone induced only the faint upper band complex (not shown). The positive control of THP1 cells stimulated with IL-4 (10 ng/ $\mathrm{ml}$ ) for $15 \mathrm{~min}$ demonstrated a strong binding complex of STAT6, which was supershifted by anti-STAT6 Ab (Fig. 7 B).

To determine if conditioned media also activated STAT DNA binding, EMSA was performed on WCE of HAEC treated with 6-d conditioned media. This resulted in activation of STAT1 (Fig. 7 C). Interestingly, this complex was more prominent than the complex detected in HAEC stimulated directly with IFN $\gamma$ and IL-4. Moreover, conditioned media resulted in a prominent binding complex of three bands using IL-4GAS as the probe. Supershift analyses demonstrated that the predominant protein binding to the IL-4GAS was STAT1, with only very low level of STAT6 detectable in the binding complex. The presence of three distinct bands using the IL4GAS probe was best appreciated after supershift of the STAT1 (Fig. $7 C$, lane 11 ). STAT proteins can bind DNA as homo- or heterodimeric STAT combinations, which have dif- 
A

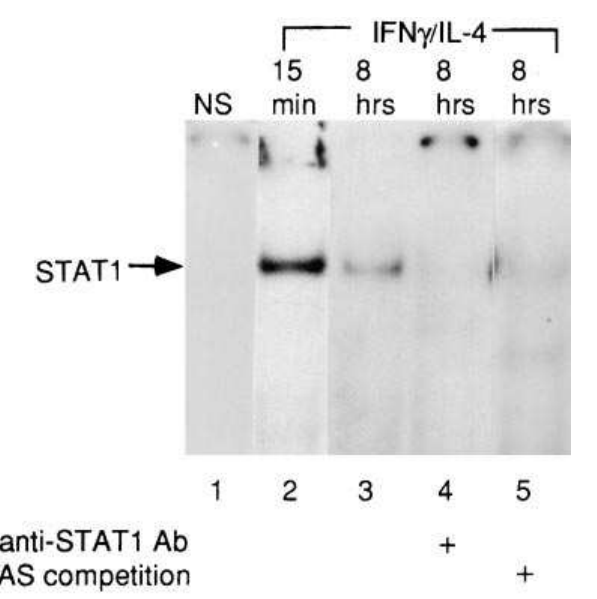

B

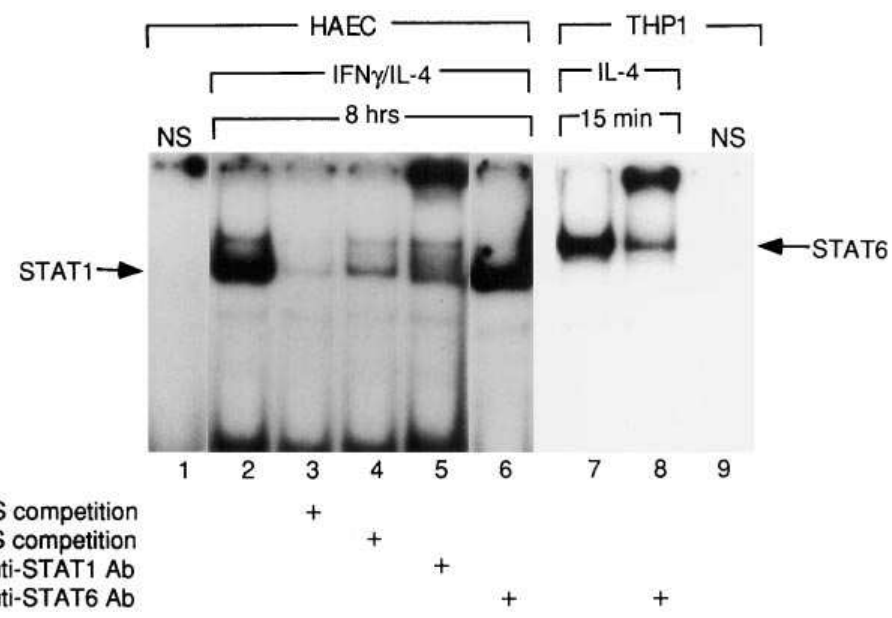

C

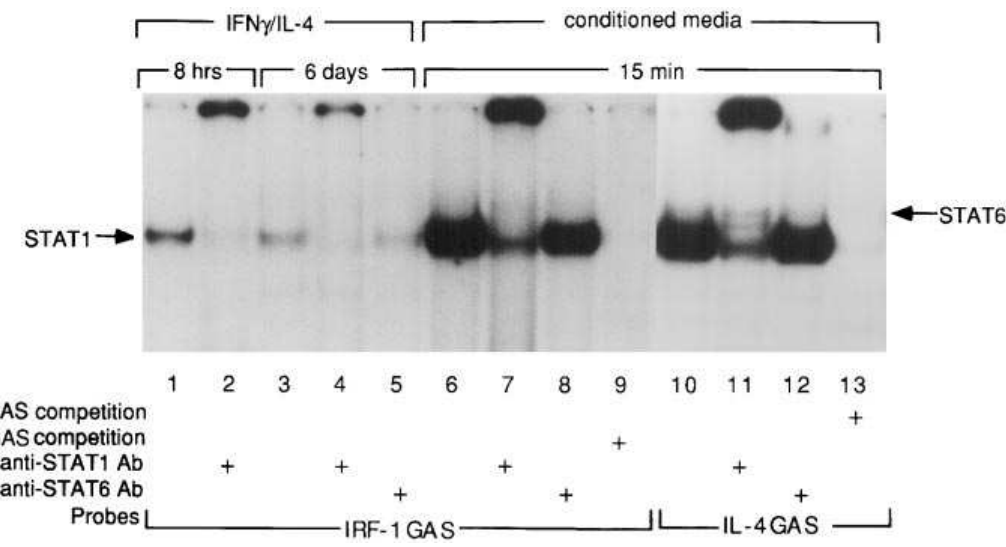

Figure 7. Activation of signal transducers and activators of transcription (STAT1 and STAT6) in HAEC stimulated with IFN $\gamma$ and IL-4. EMSA of DNA-protein complexes were resolved on nondenaturing $6 \%$ polyacrylamide gels, followed by autoradiography. $(A)$ Detection of STAT1 in HAEC. EMSA of whole cell extracts $(5 \mu \mathrm{g}$ protein/lane) from nonstimulated (NS) HAEC (lane 1), or HAEC incubated with IFN $\gamma$ and IL-4 for 15 min (lane 2), $8 \mathrm{~h}$ (lanes 3-5) were performed using ${ }^{32} \mathrm{P}$-labeled oligonucleotide containing the IRF-1GAS element. (B) Low level of STAT6 activation in HAEC. EMSA of whole cell extracts (5 $\mu \mathrm{g}$ protein/lane) from nonstimulated HAEC (lane 1), or HAEC cultured with IFN $\gamma$ and IL-4 for $8 \mathrm{~h}$ (lanes 2-6), or THP1 nonstimulated (lane 9 ) and stimulated with IL-4 (lanes 7 and 8 ) were

performed using ${ }^{32} \mathrm{P}$-labeled oligonucleotide containing the IL-4GAS element. $(C)$ Transferable mediator(s) in conditioned media activates STAT1. EMSA of whole cell extracts (5 $\mu \mathrm{g}$ protein/lane) from HAEC incubated with IFN $\gamma$ and IL-4 for $8 \mathrm{~h}$ (lanes 1 and 2 ) and $6 \mathrm{~d}$ (lanes $3-5$ ) were performed using ${ }^{32} \mathrm{P}$-labeled IRF-1GAS element, or from HAEC incubated with conditioned media for 15 min (lanes 6-13) using ${ }^{32} \mathrm{P}$-labeled IRF-1GAS element (lanes 6-9) or IL-4GAS element (lanes 10-13). Unlabeled oligonucleotide IRF-1GAS or IL-4GAS at 100 times molar excess of ${ }^{32} \mathrm{P}$-labeled, or rabbit anti-STAT1 or STAT6 polyclonal antibodies (pAb, $2 \mu \mathrm{g}$ ) were added to the binding reactions as indicated to verify STAT1 or STAT6 binding complex. Arrows designate binding complexes containing STAT1 or STAT6. Similar results were obtained in at least three experiments for each condition.

ferent sequence specificities and bind sites related to the GAS element (26). Evidence for this comes from cells stimulated with EGF or IL-6, in which three protein-DNA complexes are activated, which represent DNA interactions with STAT homodimers and heterodimers (27). Thus, the activation of three distinct protein-DNA complexes by conditioned media suggests homo- and heterodimeric complexing of STAT proteins. Based upon supershift analyses, the fastest moving complex contained STAT1 homodimers and the slowest moving complex homodimers of STAT6, with the intermediate complex representing a heterodimeric complex of STATs.

Overall, the finding of even higher levels of STAT1 activation by the conditioned media than by direct addition of cytokines IFN $\gamma$ and IL-4 suggested the presence of other mediators which are able to activate STAT1 and which are being produced by the HAEC. STAT1 tyrosine phosphorylation and translocation to the nucleus occurs in response to many growth factors and cytokines including IFN $\gamma$, IL-10, IFN $\alpha / \beta, \mathrm{EGF}$, platelet derived growth factor, granulocyte-macrophage colony stimulating factor, IL-6, IL-11, leukemia inhibitory factor, ciliary neurotrophic factor, Oncostatin $\mathrm{M}$, growth hormone, prolactin, and colony stimulating factor-1 $(26,28,29)$. While the STAT1 activation resulting from the conditioned media may be due to one of these known mediators or an as yet unidentified mediator, based upon our results, the mediator is not IFN $\gamma$ alone. Further, the mediator is unlikely to be EGF, as the HAEC are cultured in specialized LHC8 media containing EGF $(5 \mathrm{ng} / \mathrm{ml})$, and yet unstimulated cells grown in this media do not demonstrate STAT1 activation (Fig. 7, $A$ and $B$, lane 1) or iNOS expression (Fig. 2, lane 1), which emphasizes the crucial importance of cell context in understanding signaling (29).

Both IFN $\gamma$ and IL-4 are present in BAL. To ascertain if the cytokine combination of IFN $\gamma$ and IL-4 was relevant to understanding in vivo iNOS expression in human airway epithelium, levels of IFN $\gamma$ and IL-4 in the lung epithelial lining fluid were determined. Washings from normal human lungs (BAL) contained levels of both IFN $\gamma$ and IL-4 in lung epithelial lining fluid (IL-4 $=9 \pm 5 \mathrm{pg} / \mathrm{ml} \mathrm{BAL} \mathrm{fluid,} \mathrm{and} \mathrm{IFN} \gamma=33 \pm 11 \mathrm{pg} / \mathrm{ml}$ BAL fluid; mean \pm SE, $n=13$ ). Mean total protein in BAL 
fluid was $0.18 \pm 0.03 \mathrm{mg} / \mathrm{ml} \mathrm{BAL}$ (mean $\pm \mathrm{SE}, n=13$ ). Thus, these results confirm that levels of IFN $\gamma$ and IL-4 in lung epithelial lining fluid are present in vivo at levels that would lead to iNOS induction.

\section{Discussion}

The expression of iNOS in the human respiratory epithelium in vivo has been demonstrated by numerous methods (4-7), however the mechanisms leading to persistent iNOS gene expression in normal human airway epithelium are not known. Previous in vitro studies have demonstrated that, similar to other human and murine cell lines, iNOS is induced in human lung epithelial cell lines and HAEC by cytokine combinations including IFN $\gamma$, IL-1 $\beta$, and $\mathrm{TNF} \alpha(22,23)$. However, the relevance of these cytokines to iNOS expression in the human lung is unknown, and the intracellular mechanisms leading to persistent iNOS expression in human respiratory epithelium in vivo have not been determined. Maintenance of epithelial phenotype was possible in primary cells obtained from bronchi of normal volunteers as shown by positive staining for a panel of five different cytokeratins and lack of staining by vimentin, $\mathrm{CD} 3$, or CD68. As previously shown, iNOS gene induction in HAEC was demonstrated in response to cytokine combinations including IFN $\gamma$, IL- $1 \beta$, and TNF $\alpha$. Further, IFN $\gamma$ alone was sufficient to induce iNOS gene expression in HAEC, but not in BEAS2B. Although previous studies have shown the induction of iNOS in BEAS2B using reverse transcription and polymerase chain reaction (22), our results indicate that these cells do not recapitulate the behavior of primary airway epithelial cells in their response to cytokines.

Although IL-4 has been reported to inhibit iNOS expression in some studies and induce NO production in other studies $(30,31)$, the mechanisms are not clear. While IL-4 alone did not induce iNOS gene expression in HAEC, IL-4 potentiated IFN $\gamma$-induced iNOS in HAEC. The combination of IFN $\gamma$ and IL-4 provided the maximal induction of iNOS in HAEC in comparison to other cytokine combinations. The time course of iNOS induction in HAEC was delayed and prolonged after IFN $\gamma$ and IL-4 stimulation. This is in contrast to primary cultured hepatocytes, in which iNOS induction occurs in response to cytokines as early as $2 \mathrm{~h}$ with peak levels at 4-6 h (8). Similarly in A549 cells, cytokine combinations induced peak iNOS mRNA levels at $8 \mathrm{~h}$ after stimulation with decreases in mRNA at $48 \mathrm{~h} \mathrm{(22).} \mathrm{The} \mathrm{potentiation} \mathrm{of} \mathrm{mRNA} \mathrm{levels} \mathrm{by} \mathrm{IL-4} \mathrm{in} \mathrm{some}$ instances, such as vascular cell adhesion molecule 1 , has been attributed to increases in the half-life of the mRNA (32). Furthermore, stabilization of iNOS mRNA is one mechanism through which endotoxin potentiates IFN $\gamma$-induced iNOS expression in the mouse macrophage-like cell line (33). iNOS mRNA contains multiple copies of the consensus sequence AUUUA which are responsible for destabilizing mRNA (34). While the half-life of iNOS mRNA in IFN $\gamma$-stimulated HAEC was comparable to previously determined iNOS mRNA halflife (35), the addition of IL-4 to IFN $\gamma$ prolonged the half-life of iNOS mRNA by 1.8 -fold in HAEC. Thus, iNOS mRNA levels are regulated in HAEC partially at the level of mRNA stability. However, the prolongation of iNOS mRNA half-life by IL-4 still does not account for continuing iNOS mRNA expression for up to $1 \mathrm{wk}$. Possible mechanisms considered for the persistent iNOS mRNA expression in HAEC included continued signaling by cytokines from cell surface receptors or inhibition of intracellular signal decay which would lead to sustained activation of STAT1 $(19,29)$. Either of these processes could lead to continuing iNOS gene expression.

Interestingly, persistence of iNOS expression in HAEC in culture was dependent on maintaining the overlying tissue culture media (conditioned media). Further, transfer of the conditioned media to other HAEC in culture induced iNOS gene expression, while transfer of conditioned media to A549 or BEAS2B did not lead to iNOS induction. Despite minimal levels of IFN $\gamma$ in conditioned media, conditioned media transfer to other HAEC resulted in levels of iNOS induction similar to addition of fresh IFN $\gamma$ and IL-4. Signal transduction for IFNy is through tyrosine phosphorylation of STAT1 and translocation to the nucleus (19). Similarly, IL-4 mediates its effects at least in part through STAT6 activation $(18,36)$. Inhibitors of tyrosine phosphorylation have been shown to inhibit induction of iNOS by IFN $\gamma$ (37). Furthermore, binding elements for STATs in the mouse and human iNOS promoter have been described, and in the case of the mouse iNOS gene, transcriptional activation is dependent upon these elements (9). In this study, unstimulated HAEC did not demonstrate STAT1 activation, however IFN $\gamma$ stimulation rapidly activated STAT1 in HAEC. While activation of STAT1 by IFN $\gamma$ in HAEC has been demonstrated in the past (38), activation of STAT6 by IL-4 in these cells was previously unknown. Using a GAS element that preferentially binds STAT6, complexes were detected upon electrophoretic mobility shift assays but, as evidenced by supershift using STAT6 antibodies, only a minority of the protein binding to the IL-4GAS element was STAT6. Rather, STAT1 was the major protein binding to the IL-4GAS element, as might be expected since the IL-4GAS element contains the DNA consensus element for STAT1 binding $(18,36)$. Surprisingly, exposure of HAEC to conditioned media resulted in activation of STAT1 which was greater than activation by direct addition of IFN $\gamma$, suggesting that additional mediator(s) capable of activating STAT1 was generated in the culture supernatant. These results supported that continued signaling through cell surface receptors was responsible for ongoing iNOS gene expression over time in HAEC.

In general, IFN $\gamma$ binding to cell surface receptors initiates signals that are transmitted to the nucleus and lead to the rapid induction of a number of interferon-stimulated primary response genes in the absence of de novo protein synthesis (28). However, other secondary response genes are induced as a delayed response to IFN $\gamma$ and require new protein synthesis, such as MHC class II (HLA-DR) $(39,40)$. The mechanisms involved in the IFN $\gamma$-delayed secondary response gene expression are less well understood $(39,40)$. Induction of iNOS in HAEC by IFN $\gamma$ displays characteristics of a secondary response gene, such as delayed time to expression, enhancement of induction by additional cytokines (TNF, IL-1 $\beta$, IL-4), and requirement of new protein synthesis. However, the induction of iNOS in HAEC by conditioned media did not require new protein synthesis, indicating that the process of iNOS induction by conditioned media is not a secondary effect and is different than the IL-4/IFN $\gamma$-stimulated iNOS induction. Interestingly, iNOS induction by conditioned media was enhanced by cycloheximide. Previously, cycloheximide has been shown to enhance iNOS induction in mouse macrophage cell line RAW264.7 (41), and in vascular smooth muscle cells (34). The mechanism of cycloheximide enhancement of iNOS mRNA in vascular smooth muscle cells is through prolongation of the 
mRNA lifetime (34). These studies, along with our result of prolongation of iNOS half-life by IL-4, suggest that iNOS expression is partially under the control of protein factors which regulate iNOS mRNA half-life.

Results from wash-off experiments of the IFN $\gamma$ and IL-4 indicate that the majority of mediator(s) synthesis and secretion important for induction and maintenance of the iNOS gene expression in HAEC occurs between 1 and $24 \mathrm{~h}$ of cytokine stimulation. The fact that the conditioned media was not able to induce other lung epithelial cells may indicate that the response to the transferable mediator(s) is unique to the primary HAEC. The previous finding of iNOS expression in human airway epithelial cells in vivo, without expression in other resident lung cells including human macrophages (4) also supports that the response to the transferable mediator(s) is specific for the human airway epithelium. A multitude of stimuli and products have been noted to affect iNOS expression including NO (42-44). However, iNOS gene expression in HAEC was not related to NO production, as presence of NOS inhibitor did not affect iNOS gene expression. Similarly, previous reports have suggested that IL-4 and IFN $\gamma$ induce activation of iNOS gene expression through ligation of the low-affinity $\mathrm{IgE}$ receptor $\mathrm{CD} 23$ in human monocytes, keratinocytes, and eosinophils (45). CD23 may be induced by IL-4 and be cell associated or in a soluble form cleaved into the supernatant (46). However, soluble or cell-associated CD23 was not detected in cells or the conditioned media of IL-4- and IFN $\gamma$ stimulated HAEC (data not shown).

Based upon these results, IFN $\gamma$ is sufficient to induce iNOS in human airway epithelial cells, with potentiation of iNOS expression by IL-4 through prolongation of the half-life of the mRNA. Importantly, this combination of cytokines is biologically relevant to expression of iNOS in airway epithelium in vivo, as IL-4 and IFN $\gamma$ were detected in fluid lining the lung epithelium sampled from normal volunteers. Similar levels of IFN $\gamma$ and IL-4 have been detected in lung epithelial lining fluid in previous studies using various detection assays $(47,48)$. In addition, $\mathrm{CD}^{+} \mathrm{T}$ helper lymphocytes, which produce IFN $\gamma$ and IL-4, are present on the lung epithelial surface, comprising up to $9 \%$ of the total cells recovered by BAL from normal individuals $(47,49)$. Further evidence of the presence and activity of these cytokines in the epithelial lining fluid is provided by studies which demonstrate expression of IFN $\gamma$ - and IL-4inducible genes in the human airway epithelium in vivo. Specifically, intercellular adhesion molecule-1 and HLA-DR, which are selectively induced by IFN $\gamma$ in HAEC in culture (50, 51 ), are both continuously expressed by normal human airway epithelial cells in vivo (52-54). Interestingly, while human airway epithelial cells have $>80 \%$ positivity for MHC class I (HLA-A, B, and C) and II (HLA-DR) expression in vivo, similar to iNOS, the HLA-DR expression is lost when cells are removed from the lung environment. However, prolonged HLA-DR expression is maintained by culture of the cells in the presence of IFN $\gamma(52)$. Similarly, granulocyte-macrophage colony stimulating factor, which is induced by IL-4 in human airway epithelial cells in vitro (55), is expressed in up to $14 \pm 3 \%$ of normal human airway epithelial cells in vivo (56). Thus, human airway epithelium is exposed to and capable of responding to IFN $\gamma$ and IL-4, suggesting that airway epithelial cells are an important target for IFN $\gamma$ and IL-4 action in the lung.

Our results demonstrate the complex nature of the regula- tion of iNOS gene expression in airway epithelial cells, which varies even among different types of human lung epithelial cells. iNOS expression in human airway epithelial cells is dependent upon cytokine-induced mediator synthesis and secretion. The majority of the mediator(s) synthesis/secretion appears to occur early after initiating cytokine stimulation, but is relatively stable and transferable in the overlying culture media. Based upon our findings, we propose a mechanism for iNOS induction and maintenance in human airway epithelium, in which IFN $\gamma$ and IL-4 in the lung epithelial lining fluid lead to epithelial production of soluble mediator(s) that stimulate the airway epithelium in an autocrine and paracrine fashion to express iNOS. Future work will be based upon characterizing the mediator(s) and the mechanism of effect.

\section{Acknowledgments}

We thank C. Harris for BEAS2B, D. Mytych for IL-4, Genentech for IFN $\gamma$, J. Lang for photography, S. Alpert for human airway cells from postmortem tracheas, R. Oppedisano for clinical support, and $\mathrm{J}$. Voynow for critical comments on the manuscript.

This work was supported by National Institutes of Health grant HL-03117.

\section{References}

1. Schmidt, H.H.H.W., and U. Walter. 1994. NO at work. Cell. 78:919-925. 2. Stuehr, D.J., and O.W. Griffith. 1992. Mammalian nitric oxide synthases. Adv. Enzymol. Relat. Areas Mol. Biol. 65:287-346.

3. Szabo, C., and C. Thiemermann. 1995. Regulation of the expression of the inducible isoform of nitric oxide synthase. Adv. Pharmacol. 34:113-153.

4. Guo, F.H., H.R. De Raeve, T.W. Rice, D.J. Stuehr, F.B.J.M. Thunnissen, and S.C. Erzurum. 1995. Continuous nitric oxide synthesis by inducible nitric oxide synthase in normal human airway epithelium in vivo. Proc. Natl. Acad. Sci. USA. 92:7809-7813.

5. Kobzik, L., D.S. Bredt, C.J. Lowenstein, J. Drazen, B. Gaston, D. Sugarbaker, and J.S. Stamler. 1993. Nitric oxide synthase in human and rat lung: immunocytochemical and histochemical localization. Am. J. Respir. Cell Mol. Biol. 9:371-377.

6. Lundberg, J.O.N., T. Farkas-Szallasi, E. Weitzberg, J. Rinder, J. Lidholm, A. Anggard, T. Hokfelt, J.M. Lundberg, and K. Alving. 1995. High nitric oxide production in human paranasal sinuses. Nat. Med. 1:370-373.

7. Nathan, C., and Q. Xie. 1994. Regulation of biosynthesis of nitric oxide. J. Biol. Chem. 269:13725-13728.

8. De Vera, M.E., R.A. Shapiro, A.K. Nussler, J.S. Mudgett, R.L. Simmons, S.M. Morris, Jr., T.R. Billiar, and D.A. Geller. 1996. Transcriptional regulation of human inducible nitric oxide synthase (NOS2) gene by cytokines: initial analysis of the human NOS2 promoter. Proc. Natl. Acad. Sci. USA. 93:10541059 .

9. Zhang, X., V.E. Laubach, E.W. Alley, K.A. Edwards, P.A. Sherman, S.W. Russell, and W.J. Murphy. 1996. Transcriptional basis for hyporesponsiveness of the human inducible nitric oxide synthase gene to lipopolysaccharide/interferon- $\gamma$. J. Leukocyte Biol. 59:575-585.

10. Kolyada, A.Y., N. Savikovsky, and N.E. Madias. 1996. Transcriptional regulation of the human iNOS gene in vascular-smooth-muscle cells and macrophages: evidence for tissue specificity. Biochem. Biophys. Res. Commun. 220: 600-605.

11. Charles, I.G., R.M. Palmer, M.S. Hickery, M.T. Bayliss, A.P. Chubb, V.S. Hall, D.W. Moss, and S. Moncada. 1993. Cloning, characterization, and expression of a cDNA encoding an inducible nitric oxide synthase from the human chondrocyte. Proc. Natl. Acad. Sci. USA. 90:11419-11423.

12. Davis, P.B., C.L. Silski, C.M. Kercsmar, and M. Infeld. 1990. $\beta$-Adrenergic receptors on human tracheal epithelial cells in primary culture. Am. J. Physiol. 258:C71-C76.

13. Calhoun, W.J., E.C. Dick, L.B. Schwartz, and W.W. Busse. 1994. A common cold virus, rhinovirus 16 , potentiates airway inflammation after segmental antigen bronchoprovocation in allergic subjects. J. Clin. Invest. 94:22002208.

14. Reddel, R.R., Y. Ke, B.I. Gerwin, M.G. McMenamin, J.F. Lechner, R.T. Su, D.E. Brash, J.-B. Park, J.S. Rhim, and C.C. Harris. 1988. Transformation of human bronchial epithelial cells by infection with SV40 or adenovirus-12 SV40 hybrid virus, or transfection via strontium phosphate coprecipitation with a plasmid containing SV40 early region genes. Cancer Res. 48:1904-1909.

15. Boers, J.E., G.P.M. Ten Velde, and F.B.J.M. Thunnissen. 1996. P53 in 
squamous metaplasia: a marker for risk of respiratory tract carcinoma. Am. J. Respir. Crit. Care. Med. 153:411-416.

16. Dignam, J.D., R.M. Lebovitz, and R.G. Roeder. 1983. Accurate transcription initiation by RNA polymerase II in a soluble extract from isolated mammalian nuclei. Nucl. Acids Res. 11:1475-1489.

17. Pearse, R.N., R. Feinman, and J.V. Ravetch. 1991. Characterization of the promoter of the human gene encoding the high-affinity IgG receptor: transcriptional induction by $\gamma$-interferon is mediated through common DNA response elements. Proc. Natl. Acad. Sci. USA. 88:11305-11309.

18. Kotanides, H., and N.C. Reich. 1993. Requirement of tyrosine phosphorylation for rapid activation of a DNA binding factor by IL-4. Science (Wash. DC). 262:1265-1267.

19. Haque, S.J., V. Flati, A. Deb, and B.R.G. Williams. 1995. Roles of protein-tyrosine phosphatases in stat $1 \alpha$-mediated cell signaling. J. Biol. Chem. 43 : 25709-25714.

20. Archer, S. 1993. Measurement of nitric oxide in biological models. FASEB (Fed. Am. Soc. Exp. Biol.) J. 7:349-360.

21. Familletti, P.C., S. Rubinstein, and S. Pestka. 1981. A convenient and rapid cytopathic effect inhibition assay for interferon. Methods Enzymol. 78: 387-394.

22. Asano, K., C.B.E. Chee, B. Gaston, C.M. Lilly, C. Gerard, J.M. Drazen, and J.S. Stamler. 1994. Constitutive and inducible nitric oxide synthase gene expression, regulation, and activity in human lung epithelial cells. Proc. Natl. Acad. Sci. USA. 91:10089-10093.

23. Robbins, R.A., P.J. Barnes, D.R. Springall, J.B. Warren, O.J. Kwon, L.D.K. Buttery, A.J. Wilson, D.A. Geller, and J.M. Polak. 1994. Expression of inducible nitric oxide in human lung epithelial cells. Biochem. Biophys. Res. Commun. 203:209-218.

24. Kleinert, H., C. Euchenhofer, I. Ihrig-Biedert, and U. Forstermann. 1996. Glucocorticoids inhibit the induction of nitric oxide synthase II by downregulation of cytokine-induced activity of transcription factor nuclear factorкB. Mol. Pharmacol. 49:15-21.

25. Kamijo, R., H. Harada, T. Matsuyama, M. Bosland, J. Gerecitano, D. Shapiro, J. Le, S.I. Koh, T. Kimura, S.J. Green, T.W. Mak, T. Taniguchi, and J. Vilcek. 1994. Requirement for transcription factor IRF-1 in NO synthase induction in macrophages. Science (Wash. DC). 263:1612-1615.

26. Hill, C.S., and R. Treisman. 1995. Transcriptional regulation by extracellular signals: mechanisms and specificity. Cell. 80:199-211.

27. Schindler, C., and J.E. Darnell, Jr. 1995. Transcriptional responses to polypeptide ligands: the jak-stat pathway. Annu. Rev. Biochem. 64:621-651.

28. Darnell, J.E., Jr., I.M. Kerr, and G.R. Stark. 1994. Jak-stat pathways and transcriptional activation in response to IFNs and other extracellular signaling proteins. Science (Wash. DC). 264:1415-1420.

29. Marshall, C.J. 1995. Specificity of receptor tyrosine kinase signaling: transient versus sustained extracellular signal-regulated kinase activation. Cell. 80:179-185.

30. Kolb, J.P., N. Paul-Eugene, C. Damais, K. Yamaoka, J.C. Drapier, and B. Dugas. 1994. Interleukin-4 stimulates cGMP production by IFN- $\gamma$-activated human monocytes. J. Biol. Chem. 269:9811-9816.

31. Sands, W.A., V. Bulut, A. Severn, D. Xu, and F.Y. Liew. 1994. Inhibition of nitric oxide synthesis by interleukin-4 may involve inhibiting the activation of protein kinase C epsilon. Eur. J. Immunol. 24:2345-2350.

32. Iademarco, M.F., J.L. Barks, and D.C. Dean. 1995. Regulation of vascular cell adhesion molecule 1 expression by IL- 4 and TNF- $\alpha$ in cultured endothelial cells. J. Clin. Invest. 95:264-271.

33. Weisz, A., S. Oguchi, L. Cicatiello, and H. Esumi. 1994. Dual mechanism for the control of inducible-type NOS synthase gene expression in macrophage during activation by interferon- $\gamma$ and bacterial lipopolysaccharide. $J$. Biol. Chem. 269:8324-8333.

34. Hattori, Y., and S.S. Gross. 1995. Cycloheximide induces nitric oxide synthase mRNA in vascular smooth muscle cells by prolonging mRNA lifetime. Biochem. Mol. Biol. Int. 37:439-445.

35. Robbins, R.A., D.R. Springall, J.B. Warren, O.J. Kwon, L.D.K. Buttery, A.J. Wilson, I.M. Adcock, V. Riveros-Moreno, S. Moncada, J. Polak, and P.J. Barnes. 1994. Inducible nitric oxide synthase is increased in murine lung epithelial cells by cytokine stimulation. Biochem. Biophys. Res. Commun. 198:835-843.

36. Hou, J., U. Schindler, W.J. Henzel, T.C. Ho, M. Brasseur, and S.L. McKnight. 1994. An interleukin-4-induced transcription factor: IL-4 stat. Science (Wash. DC). 265:1701-1706.
37. Dong, Z., X. Qi, K. Xie, and I.J. Fildler. 1993. Protein tyrosine kinase inhibitors decrease induction of nitric oxide synthase activity in lipopolysaccharide-responsive and lipopolysaccharide-nonresponsive murine macrophages. $J$. Immunol. 151:2717-2724.

38. Look, D.L., M.R. Pelletier, and M.J. Holtzman. 1994. Selective interaction of a subset of interferon- $\gamma$ response element-binding proteins with the intercellular adhesion molecule-1(ICAM-1) gene promoter controls the pattern of expression of epithelial cells. J. Biol. Chem. 269:8952-8958.

39. Williams, B.R.G. 1991. Transcriptional regulation of interferon-stimulated genes. Eur. J. Biochem. 200:1-11.

40. Pestke, S., J.A. Langer, K.C. Zoon, and C.E. Samuel. 1987. Interferons and their actions. Annu. Rev. Biochem. 56:727-777.

41. Oguchi, S., A. Weisz, and H. Esumi. 1994. Enhancement of inducibletype NO synthase gene transcription by protein synthesis inhibitors: activation of an intracellular signal transduction pathway by low concentrations of cycloheximide. FEBS Lett. 338:326-330.

42. Muhl, H., and J. Pfeilschifter. 1995. Amplification of nitric oxide synthase expression by nitric oxide in interleukin $1 \beta$-stimulated rat mesangial cells. J. Clin. Invest. 95:1941-1946.

43. Colasanti, M., T. Persichini, M. Menegazzi, S. Mariotto, E. Giordanol, C.M. Caldarera, V. Sogos, G.M. Lauro, and H. Suzuki. 1995. Induction of nitric oxide synthase mRNA expression: suppression by exogenous nitric oxide. $J$. Biol. Chem. 270:26731-26733.

44. Sheffler, L.A., D.A. Wink, G. Melillo, and G.W. Cox. 1995. Exogenous nitric oxide regulates IFN- $\gamma$ plus lipopolysaccharide-induced nitric oxide synthase expression in mouse macrophages. J. Immunol. 155:886-894.

45. Vouldoukis, I., V. Riveros-Moreno, B. Dugas, F. Quaaz, P. Becherel, P. Debre, S. Moncada, and M.D. Mossalayi. 1995. The killing of leishmania major by human macrophages is mediated by nitric oxide induced after ligation of the FceRII/CD23 surface antigen. Proc. Natl. Acad. Sci. USA. 92:7804-7808.

46. Rousselet, G., M. Billaud, P. Busson, G. Lenoir, and L.T. Tursz. 1991. CD23 and epithelial cells. Monogr. Allergy. 29:186-195.

47. Walker, C., E. Bode, L. Boer, T.T. Hansel, K. Blaser, and J.-C.V. Virchow, Jr. 1992. Allergic and nonallergic asthmatics have distinct patterns of T-cell activation and cytokine production in peripheral blood and bronchoalveolar lavage. Am. Rev. Respir. Dis. 146:109-115.

48. Cembrzynska-Nowak, M., E. Szklarz, A.D. Inglot, and J.A. Teodorczyk-Injeyan. 1993. Elevated release of tumor necrosis factor-alpha and interferon-gamma by bronchoalveolar leukocytes from patients with bronchial asthma. Am. Rev. Respir. Dis. 147:291-295.

49. Rom, W.N., and W.D. Travis. 1992. Lymphocyte-macrophage alveolitis in nonsmoking individuals occupationally exposed to asbestos. Chest. 101:779-786.

50. Saunders, N.A., R.J. Smith, and A.M. Jetten. 1994. Differential responsiveness of human bronchial epithelial cells, lung carcinoma cells, and bronchial fibroblasts to interferon-gamma in vitro. Am. J. Respir. Cell Mol. Biol. 11:147-152.

51. Look, D.C., S.R. Rapp, B.T. Keller, and M.J. Holtzman. 1993. Selective induction of intercellular adhesion molecule-1 by interferon-gamma in human airway epithelial cells. Am. J. Physiol. 263:L79-L87.

52. Rossi, G.A., O. Sacco, B. Balbi, S. Oddera, T. Mattioni, G. Corte, C Ravazzoni, and L. Allegra. 1990. Human ciliated bronchial epithelial cells: expression of the HLA-DR antigens and of the HLA-DR alpha gene, modulation of the HLA-DR antigens by gamma-interferon and antigen-presenting function in the mixed leukocyte reaction. Am. J. Respir. Cell Mol. Biol. 3:431-439.

53. Glanville, A.R., H.D. Tazelaar, J. Theodore, E. Imoto, R.V. Rouse, J.C. Balewin, and E.D. Robin. 1989. The distribution of MHC class I and II antigens on bronchial epithelium. Am. Rev. Respir. Dis. 139:330-334.

54. Stefano, A.D., P. Maesterlli, A. Roggeri, G. Turato, S. Calabro, A. Potena, C.E. Mapp, A. Ciaccia, L. Covacev, L.M. Fabbri, and M. Saetta. 1994. Upregulation of adhesion molecules in the bronchial mucosa of subjects with chronic obstructive bronchitis. Am. J. Respir. Crit. Care. Med. 149:803-810.

55. Nakamura, Y., M. Azuma, Y. Okano, T. Sano, T. Takahashi, Y. Ohmoto, and S. Sone. 1996. Upregulatory effects of interleukin-4 and interleukin13 but not interleukin-10 on granulocyte/macrophage colony-stimulating factor production by human bronchial epithelial cells. Am. J. Respir. Cell Mol. Biol. 15:680-687.

56. Sousa, A.R., R.N. Poston, S.J. Lane, J.A. Nakhousteen, and T.H. Lee. 1993. Detection of GM-CSF in asthmatic bronchial epithelium and decrease by inhaled corticosteroids. Am. Rev. Respir. Dis. 147:1557-1561. 